\title{
CORRELATION BETWEEN API 20 STREP AND MULTIPLEX PCR FOR IDENTIFICATION OF ENTEROCOCCUS SPP. ISOLATED FROM BRAZILIAN FOODS
}

\author{
Bruna C. Gomes ${ }^{1}$; Carolina T. Esteves ${ }^{2}$; Izabel C.V. Palazzo²; Ana Lúcia C. Darini²; Bernadette D.G. M. Franco; \\ Elaine C.P. de Martinis ${ }^{2 *}$
}

${ }^{1}$ Faculdade de Ciências Farmacêuticas, Universidade de São Paulo, São Paulo, SP, Brasil; ${ }^{2}$ Faculdade de Ciências Farmacêuticas de Ribeirão Preto, Universidade de São Paulo, Ribeirão Preto, SP, Brasil

Submitted: April 18, 2007; Returned to authors for corrections: September 09, 2007; Approved: September 12, 2007.

\begin{abstract}
We evaluated the suitability of API 20 STREP and multiplex PCR to speciate 52 Enterococcus spp. obtained from Brazilian foods. A high percentage of isolates (78.9\%) presented discrepant results between evaluated tests. Similar results were obtained for six E. faecalis and five E. faecium. The PCR multiplex was more effective than API 20 STREP for complete identification of the isolates.
\end{abstract}

Key words: Enterococcus spp., identification, API 20 STREP, PCR multiplex, foods

Enterococci are commonly found in soil, water, plants, vegetables and foods $(6,9)$. This genus includes more than 20 species, being $E$. faecium and E. faecalis the most commonly found $(7,8)$. However, failure in the identification of other species is a matter of concern specially due to the emergence of antibiotic resistant enterococcal strains (12).

Identification of enterococci species is generally done by conventional phenotypic and biochemical tests even so molecular methods are becoming the choice tests for bacterial identification (1-3).

There are some kits available for a rapid identification of Enterococcus spp. such as ID 32 STREP, API 20 STREP, API 50CH, Api zym (BioMérieux, France) and Phene Plate PhP Plate System (PhPlate Microplate Techniques, Sweden). However, according to Facklam et al. (7) these tests should be carefully used since most of them only correctly identify E. faecalis. The API 20 STREP strip contains 20 microtubes with dehydrated substrates necessary to detect enzymatic activity and fermentation of sugars. The results are obtained within $24-48$ hours, and the identification is based on numerical analysis after a visual interpretation of color changes (BioMérieux, France).

The purpose of the present work was to compare the biochemical test - API 20 STREP system and a multiplex
Polymerase Chain Reaction (PCR) using specific primers for identification of Enterococcus spp. obtained from Brazilian foods.

Fifty two Enterococcus spp. isolates were initialy identified in our lab at genus level based on Gram stain, catalase reaction, growth in de Man Rogosa Sharpe broth - MRS (Oxoid, UK) at $10^{\circ} \mathrm{C}$ and $45^{\circ} \mathrm{C}, \mathrm{MRS}$ broth with $6.5 \% \mathrm{NaCl}, \mathrm{MRS}$ broth $\mathrm{pH} 9.6$ and production of PYR (L-pyrrolidonyl- $\beta$-naphthylamide). The presumptive enterococcal isolates were speciated by API 20 STREP (BioMérieux, France), used for identification of streptococci and enterococci, according to the protocol provided by the manufacturer.

Multiplex PCR was performed according to protocol described by Dutka-Malen et al. (5). Primers were used to amplify the genes $d d l$ of E. faecalis, $d d l$ of E. faecium, vanC-1 of E. gallinarum, vanC-2 and vanC-3 of E. casseliflavus. Overnight cultures of Enterococcus spp. were harvested from trypticase soy agar with $0.6 \%$ yeast extract (TSAYE) and transferred to tubes containing $100 \mu \mathrm{l}$ of PCR water (w-3500Sigma, USA). This suspension was vortexed, centrifuged for ca. 15 seconds and the supernatant was used as template. The reaction was performed on a DNA thermal cycler (Mastercycler - Eppendorf, Germany) in a final volume of $25 \mu$ containing 60

*Corresponding Author. Mailing address: Faculdade de Ciências Farmacêuticas de Ribeirão Preto - Universidade de São Paulo, Ribeirão Preto, Brazil. Tel.: (16) 3602-4267 ou (16) 3633-1936. E-mail: edemarti@usp.br 
ng of DNA as template, $25 \mathrm{pmol}$ of each primer, $0.2 \mathrm{mM}$ of each nucleotide, $2 \mathrm{mM}$ of buffer with $\mathrm{MgCl}_{2}$ and $0.625 \mathrm{U}$ of Taq DNA polymerase. Amplification conditions were: initial denaturation at $94^{\circ} \mathrm{C}-2 \mathrm{~min}, 30$ cycles at $94^{\circ} \mathrm{C}-1 \mathrm{~min}, 54^{\circ} \mathrm{C}-1 \mathrm{~min}, 72^{\circ} \mathrm{C}-1 \mathrm{~min}$, and final extension at $72^{\circ} \mathrm{C}-10 \mathrm{~min}$. PCR products were electrophorezed on $1.0 \%$ agarose and stained with ethidium bromide (5). The strains E. faecalis NCTC 775, E. faecium NCTC 7171, E. gallinarum NCTC 12359 and E. casseliflavus NCTC 12361 were used as controls.

Table 1 shows the comparison of the results obtained using the two methodologies for identification of 52 Enterococcus spp. isolates. Only six E. faecalis isolates $(11.5 \%)$ and five $(9.6 \%)$ E. faecium isolates presented the same result by using API 20 STREP and PCR. The remaining 41 isolates (78.9\%) presented discrepant results. Eight out of eleven isolates identified as $E$. durans by API 20 STREP were identified as E.faecium in the PCR, and the remaining three isolates could not be identified using the primers used in the study.

Three isolates classified as Aerococcus viridans by API 20 STREP, when tested by PCR, were identified as E. gallinarum $(\mathrm{n}=2)$ and $E$. casseliflavus $(\mathrm{n}=1)$. Five isolates identified as Leuconostoc sp. by API 20 STREP were also classifed as E. faecium when PCR was used. All five isolates identified as $E$. avium by API 20 STREP, were classified as E. faecalis $(\mathrm{n}=3), E$. faecium $(\mathrm{n}=1)$ and E. casseliflavus $(\mathrm{n}=1)$.

The multiplex PCR used in the study was more effective than API 20 STREP for identification of the species of several isolates: seven isolates identified only at genus level by API 20 STREP could be identified as E. faecium $(\mathrm{n}=6)$ and E. faecalis $(n=1)$ using PCR. Ten isolates were not identified by API 20 STREP, however the PCR assay identified these strains as: $E$. faecalis $(\mathrm{n}=3)$, E. faecium $(\mathrm{n}=5)$ and E. casseliflavus $(\mathrm{n}=1)$. One isolate could not be identified regardless the method of identification used.

Our results are in accordance with those obtained by other authors who observed that commercial systems commonly fail to differentiate Enterococcus spp. correctly $(3,7,12,14)$.
Robredo et al. (11) used the API20 STREP to identify enterococci obtained from foods of animal origin and compared the results with those obtained using colony hybridization. They did not observe discrepant results for E. faecalis but observed that eight isolates identified as E. durans and E. casseliflavus by the API20 STREP were actually E. faecium according to the molecular method.

Devriese et al. (3) also noted that the API 20 STREP was able to correctly identify E. faecalis but did not present all the necessary tests for a correct identification of other species. Morrison et al. (10) affirmed that the recognition of new and atypical species of Enterococcus spp. creates difficulties for an appropriate identification of this genus and indicates the need of including further tests in the commercially available systems (4). Moreover, according to Willey et al. (13), the emergence of antibiotic resistant enterococci demands for more accurate identification of species less commonly associated with clinical infections.

In the present work, the multiplex PCR used to identify Enterococcus spp. was based in the amplification of specific Dalanyl-D-alanine ligases of E. faecalis and E. faecium and related enzymes associated with glycopeptide resistance of $E$. gallinarum and E. casseliflavus (5). On the other hand, biochemical tests were based on visual interpretation of results and these readings are subjective and more prone to misinterpretation.

Finally, our study provided strong evidence that a number of Enterococcus spp. strains may be misidentified when only biochemical tests are used. Besides this, considering the costs and time of analysis, PCR is a cheaper, faster and more specific method to perform identification of Enterococcus spp.

\section{ACKNOWLEDGEMENTS}

This work was funded by FAPESP (The State of São Paulo Research Foundation, Brazil, process 03/11986-2). B.C. Gomes also thanks CNPq (National Council for Scientific and Technological Development, Brazil) for the PhD fellowship.

Table 1. Identification of Enterococcus spp. isolates by API 20 STREP(Biomérieux, France) and multiplex PCR

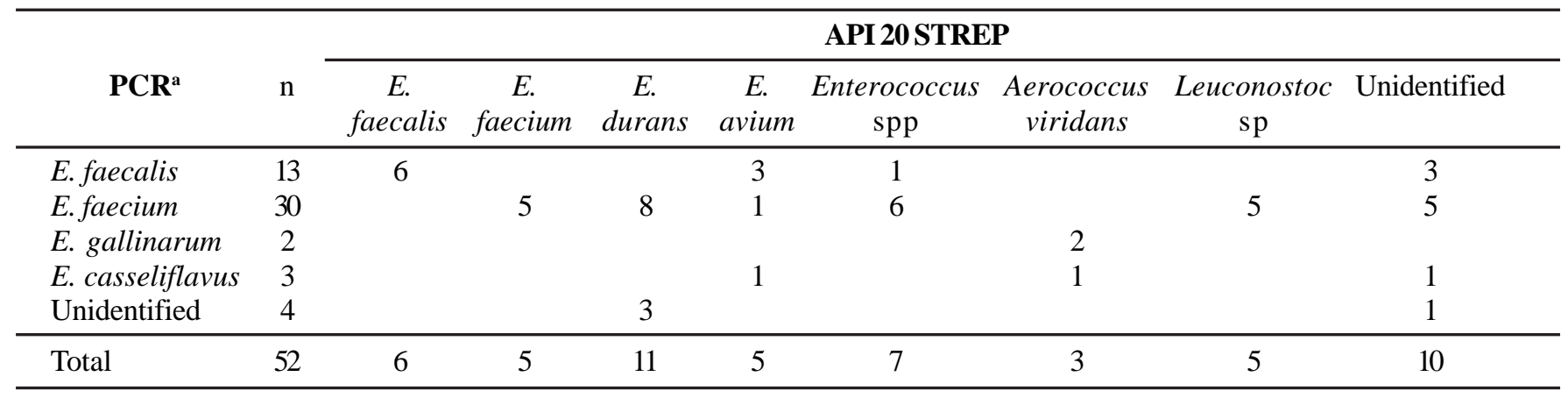

${ }^{\mathrm{a}}$ Gold Standard test. 


\section{RESUMO}

\section{Correlação entre API 20 STREP e PCR multiplex para identificação de Enterococcus spp. isolados de amostras de alimentos no Brasil}

A identificação das espécies de 52 Enterococcus spp. isolados de amostras de alimentos foi realizada empregando-se duas metodologias: sistema API 20 STREP e PCR multiplex. Os resultados obtidos revelaram que $78,9 \%$ dos isolados apresentaram resultados diferentes nos dois testes utilizados. Apenas seis E. faecalis e cinco E. faecium apresentaram resultados concordantes pelos dois métodos. PCR multiplex permitiu a identificação completa de um número significantemente maior de enterococos do que o sistema API 20STREP.

Palavras-chave: Enterococcus spp., identificação, API 20 STREP, PCR multiplex, alimentos

\section{REFERENCES}

1. Chingwaru, W.; Mpuchane, S.F.; Gashe, B.A. (2003). Enterococcus faecalis and Enterococcus faecium isolates from milk, beef, and chicken and their antibiotic resistance. J. Food Prot., 66, 931-936.

2. Devriese, L.A.; Pot, B.; Collins, M.D. (1993). Phenotypic identification of the genus Enterococcus and differentiation of phylogenetically distinct enterococcal species and species groups. $J$. Appl. Bacteriol., 75, 399-408.

3. Devriese, L.A.; Pot, B.; Damme, L.V.; Kersters, K.; Haesebrouck, F. (1995). Identification of Enterococcus species isolated from foods of animal origin. Int. J. Food Microbiol., 26, 187-197.
4. Domig, K.J.; Mayer, H.K.; Kneifel, W. (2003). Methods used for the isolation, enumeration, characterization and identification of Enterococcus spp. 2. Pheno-and genotypic criteria. Int. J. Food Microbiol., 88, 165-188.

5. Dutka-Malen, S.; Evers, S.; Courvalin, P. (1995). Detection of glycopeptide resistance genotypes and identification to the species level of clinically relevant enterococci by PCR. J. Clin. Microbiol., 33, 24-27.

6. Eaton, T.J.; Gasson, M.J. (2001). Molecular screening of Enterococcus virulence determinants and potential for genetic exchange between food and medical isolates. Appl. Environ. Microbiol., 67, 1628-1635.

7. Facklam, R.; Teixeira, L.M. Enterococcus. In: Murray, P.R.; Baron, E.J.; Jorgensen, J.H.; Pfaller, M.A.; Yolken, R.H. (2003). Manual Clin. Microbiol. 8 ed. Washington D.C.: ASM Press, p.422-433.

8. Foulquié-Moreno, M.R.; Sarantinopoulos, P.; Tsakalidou, E.; De Vuyst, L. (2006). The role and application of enterococci in food and health. Int. J. Food Microbiol., 106, 1-24.

9. Giraffa, G. (2002). Enterococci from foods. FEMS Microbiol. Rev., 26, 163-171.

10. Morrison, D.; Woodford, N.; Cookson, B. (1997). Enterococci as emerging pathogens of humans. J. Appl. Microbiol., 83, 89S-99S.

11. Robredo, B.; Singh, K.V.; Baquero, F.; Murray, B.E.; Torres, C. (2000). Vancomycin-resistant enterococci isolated from animals and food. Int. J. Microbiol., 54, 197-204.

12. Velasco, D.; Perez, S.; Peña, F.; Dominguez, M.A.; Cartelle, M.; Molina, F.; Moure, R.; Villanueva, R.; Bou, G. (2004). Lack of correlation between phenotypic techniques and PCR-based genotypic methods for identification of Enterococcus spp. Bacteriol., 49, 151156.

13. Willey, B.M.; Jones, R.N.; McGeer, A.; Witte, W.; French, G.; Roberts, R.B.; Jenkins, S.G.; Nadler, H.; Low, D.E. (1999). Practical approach to the identification of clinically relevant Enterococcus species. Diagn. Microbiol. Infect. Dis., 34, 165-171.

14. Winston, L.G.; Pang, S.; Haller, B.L.; Wong, M.; Chambers III, H.F.; Perdreau-Remington, F. (2004). API 20 STREP identification system may incorrectly speciate enterococci with low level resistance to vancomycin. Diagn. Microbiol. Infect. Dis., 48, 287-288. 